\title{
ГЕНЕЗА ЧИТАЊА КЊИЖЕВНОГ ДЈЕЛА ПЕТРА КОЧИЋА
}

(Кюига о Петру Кочићу, прир. Душко Певуља, Завод за уџбенике и наставна средства, Источно Ново Сарајево, 2021)

Постоје писци српске књижевности чије дјело независно од било каквих актуелних поетика и теоријско-методолошких приступа привлачи наглашено интересовање критике и публике. Несумњиво је међу њима и Петар Кочић (1877-1916), који дуже од сто двадесет година представља подједнак изазов за читање и тумачење. У складу са том тврдњом објављен је 2021. године тематски зборник/хрестоматија под називом Кюига o Петру Кочићy, који је приредио др Душко Певуља, професор Филолошког факултета Универзитета у Бањој Луци, а објавио је Завод за уџбенике и наставна средства Републике Српске у Источном Новом Сарајеву. Зборник је обухватио укупно 21 студију у којима је представљена рецепција књижевног дјела Петра Кочића у српској књижевности и култури током читавог 20. и у почетним деценијама 21. вијека.

Критичко читање књижевног дјела Петра Кочића веома је интензивно од појаве првих његових књига приповједака, а за више од једног вијека трајања обухватило је готово три хиљаде библиографских јединица. Подсјећамо на чињеницу да је три књиге Кочићевих приповједака под насловом $C$ планине и испод планине, које су објављене у Сремским Карловцима 1902, у Загребу 1904, као и у Београду 1905. године, а затим и Јазавца пред судом у Београду 1906. године, као и других дјела овога писца у каснијим годинама, међу којима издвајамо збирку приповједака Јауци са Змијағьа (1910), као и сатиру Суданија (1911), пропратило на веома афирмативан начин више истакнутих књижевних критичара. Издвајамо међу њима имена Марка Цара, А. Г. Матоша, Илије Ивачковића, Павла Лагарића, Владимира Гаћиновића, Милана Савића, Јована Скерлића, Павла Поповића, Бранка Лазаревића, Милана Богдановића, Милана Карановића, Васа Глушца, Јована Кршића и др. Међу њима указујемо и на имена истакнутих књижевника, попут Вељка Петровића, Алексе Шантића, Јована Дучића, Исидоре Секулић, Ива Андрића и др.

Само ријетки српски књижевни критичари су писали негативно о Кочићевој првој приповједачкој књизи, попут Данила Живаљевића у 
Колу 1902. године, али је било неупоредиво више похвалних и подстицајних критичких осврта, драгоцјених за даљи приповједачки рад младог писца. Важно је овом приликом посебно нагласити чињеницу да је Јован Скерлић критички приказао све три поменуте приповједачке књиге Петра Кочића С планине и испод планине $(1902,1904,1905)$, те да је посебан подстрек за Кочића представљао Скерлићев похвални приказ прве приповједачке књиге, објављен у Српском књижевном гласнику 1902. године. Истакао је Скерлић тада много приповједачких врлина младога писца, а посебно је издвојио Кочићев „борбени национализам“, наглашену љубав према сељаку са Змијања, као и чињеницу да је „планину описивао свежијим и јачим бојама но ико пре њега“. То су само неки од атрибута због којих је Скерлић видио у Кочићу једног од „најоригиналнијих сувремених писаца наших“ (СКЕРЛИЋ 2021: 22).

Први зборник радова о Кочићевом дјелу, под насловом Споменииза Петра Кочића објављен је у Београду 1928. године, са текстовима Владимира Ћоровића, Милана Стојмировића Јовановића и Милана Карановића. Убрзо иза тога објављена су у редакцији Зоре М. Вуловић у двије књиге Целокупна дела Петра Кочића (Народна просвета, Београд, 1932). Прву монографију о Кочићевом дјелу написао је Бранко Чубриловић, Петар Кочић и юегово доба (1934). Важно је поводом помињања ове књиге напоменути да је управо заслугом Душка Певуље урађено њено репринт издање у Бањој Луци 2016. године, са исцрпним Певуљиним поговором у коме је указано на савремену актуелност и вриједност студије, као и на личност неправедно заборављеног истраживача Бранка Чубриловића.

Иза појаве Целокупних дела 1932. године објављено је више издања Кочићевих сабраних дјела. Указујемо на она из 1967. године у редакцији Тодора Крушевца, из 1986. године у редакцији Бранка Милановића, као и 2002. године у редакцији Ненада Новаковића и Николе Цветковића. У међувремену је написано више монографија (Тодор Крушевац, Миодраг Вулин, Драгољуб Влатковић, Горан Максимовић, Станиша Тутњевић, Ненад Новаковић и сл.), урађене су библиографије и допуне библиографија (Тодор Крушевац, Драгољуб Влатковић и Голуб Добрашиновић, Јован Н. Ивановић), као и зборници радова и тематски избори крижевнокритичких текстова. Указујемо овом приликом на зборник радова Петар Кочић данас у издању Академије наука и умјетности Републике Српске у Бањој Луци, 2009. године, као и на тематски зборник/хрестоматију Јована Н. Ивановића Петар Кочић у паралелама (2002).

Наведени кратак преглед само неких од истакнутих библиографских јединица указује колико је био захтјеван приређивачки посао Душка Певуље и колико је подразумијевао добру информисаност и упућеност у ту литературу, као и прецизну методолошко-приређивачку кон- 
цепцију за израду ове књиге. Подсјећамо се укратко овом приликом и на чињеницу да је Завод за уџбенике и наставна средства, такође уз приређивачки рад Душка Певуље, објавио 2019. године Књигу Петра Кочића, у којој су обједињени бројни белетристички („,литерарни у основном одређењу") текстови овога писца објављени у периодици. Тим издањем, његовим садржајем и насловом, потврђено је оно што је Певуља у тумачењу и презентовању Кочићевог дјела више пута нагласио да је у поетичком, тематско-мотивском и идејном основу суштински ријеч о „писцу једне књиге” (PEVULJ 2021: 5-17). Једноставније речено већ објављена издања Кочићевих књига, издања сабраних и одабраних дјела, као и издање поменуте Кюиге Петра Кочића и тематског зборника Кюига о Петру Кочићy, представљају комплементарне публикације и омогућавају савременом читаоцу да стекне систематичан увид у пишчево књижевно дјело и разнолике видове његовог досадашњег тумачења.

Къига о Петру Кочићу, која се налази пред нама, представља врсту тематског зборника/хрестоматије са репрезентативним, старијим и новијим, радовима о Кочићу, чијим избором и распоредом је приређивач настојао да назначи основне видове и путање рецепције магистралног дјела овога несумњивог класика српске приповиједне прозе. Сачињен је из уводне Певуљине студије „Књижевно дјело Петра Кочића у интерпретативним огледањима", у којој је дат систематичан поглед на рецепцију Кочићевог дјела од почетка 20. вијека до наших дана, као и четири цјелине у којима су разврстани репрезентативни огледи написани о дјелу овога писца. У првој цјелини под насловом „Књижевноисторијски статус" уврштени су огледи Јована Скерлића, Јована Деретића, Предрага Палавестре и Славка Леовца. У другој цјелини под насловом „Књижевнокритичка и естетичка канонизација” уврштени су огледи Бранка Лазаревића, Јована Дучића, Јована Кршића, Исидоре Секулић, Ива Андрића. У трећој цјелини под насловом „Видови тумачења” налазе огледи Бранка Милановића, Миодрага М. Вулина, Предрага Лазаревића, Светозара Кољевића, Николе Кољевића и Радована Вучковића. У четвртој цјелини под насловом „Ка новим тумачењима” налазе се огледи Станише Тутњевића, Стојана Ђорђића, Горана Максимовића, Давора Миличевића, Ранка Поповића, као и Милоша Ковачевића. На крају књиге дати су „Библиографски подаци о текстовима", као и приређивачке напомене које указују на концепцију и начин систематизовања рукописа Кюиге о Петру Кочићу.

Наведени избор на добар начин указује на различите аспекте читања Кочићевог дјела. У првој цјелини су уврштене студије које указују на књижевноисторијски контекст и стилско-поетички статус Кочићевог дјела. Несумњиви пионирски значај у свему томе имао је Скерлићев поглед на модерност Кочићевог дјела, као и добра књижевноисторијска 
контекстуализација тог дјела у историјама српске књижевности Јована Деретића и Предрага Палавестре. Слична позиција Кочићевог дјела препознатљива је и у Леовчевој књизи Портети српских писаца 19. века са наглашеним укрштањем интерпретативног и синтетичког приступа, који потврђује креативни спој реалистичко-натуралистичког и модерног импресионистичко-неоромантичарског приповиједног поступка и стилско-поетичких особина.

Посебно се осврћемо на расправу Јована Деретића, која је углавном уобличена у његовој Историји српске кюижевности (1983), а која Кочића сагледава као модерног реалисту који је заједно са Станковићем и Ћипиком, Милићевићем и Ускоковићем, поставио темеље модерној српској прози на почетку 20. вијека. Деретић наглашава средишње константе Кочићевог погледа на свијет и књижевност, а које се најкраће могу исказати кроз неколико синтагми: љубав према отаџбини, према српству, завичају и босанском човјеку, трагичан доживљај ропства, као и његова дубока повезаност са природом, „према дивљим планинама завичаја" (DERETIĆ 2021: 24). Кочићев бунт Деретић доводи у везу са насљеђем српском романтизма, прије свега Јакшићевог дјела, као и са реализмом Максима Горког из страних књижевности. Пјесме у прози: „Јелике и оморике”, „Молитва”, „Тежак”, „Кмети”, Слободи”, карактерише као „изванредне”, а приповијетке „Јаблан”, „Мргуда”, „Вуков гај”, „Мрачајски прото” и „Кроз мећаву”, смјешта у сам врх српске приповијетке. Циклус прича о Симену Ђаку: „Зулум Симеуна Ђака”, „Мејдан Симеуна Ђака”, „Истинити зулум Симеуна Ђака”, „Ракијо, мајко”, „Из староставне књиге Симеуна Ђака”; Деретић сагледава као „неку врсту прозног комичног епоса, у коме се у омамљујућој атмосфери око ракијског казана испредају приче о стварним и измишљеним јунаштвима" (DERETIĆ 2021: 26). Посебну хумористичко-сатиричку димензију Кочићевог књижевног говора сагледава кроз карактеризацију Давида Штрпца у једночинки „Јазавац пред судом”, док „Суданију” чита у кључу „политичких сатира”.

У другој цјелини су уврштене расправе са наглашеним импресионистичким књижевнокритичким приступом и добрим уочавањем и канонизацијом неких од незаобилазних естетских квалитета Кочићевог дјела. Указујемо на тумачења Бранка Лазаревића, на читања Јована Дучића и Јована Кршића, а посебно Исидоре Секулић и Ива Андрића, у којима је указано на поднебље, људе и језик Петра Кочића као основу његове приповиједне имагинације и умјетничке слике свијета. Андрић је сагледао Кочића као свог духовног и књижевног претходника, не само на плану тематизације босанскохерцеговачког простора у вијековима османског и аустријског ропства, него и на поетичком, стилско-језичком и књижевном плану, посебно у равни карактеризације јунака и поступка 
имагинације историје овога простора.

Овом приликом се посебно осврћемо на студију Бранка Лазаревића која је објављена у књизи Импресије из књижевности (1912). У уводу је наглашено да је српска приповијетка на почетку 20. вијека била у знаку четири имена: Боре Станковића, Ива Ћипика, Петра Кочића и Светозара Ћоровића. При томе је Лазаревић указао и на регионалну распрострањеност приповијетке тако да се „поклапала са нашим националним тереном". Све то јој даје специфичну разноликост тонова, боја, карактера, начина живота, обичаја и језичких особености. „Јужни део има свога хроничара у Борисаву Станковићу, Далмација има Ива Кипика, Босна Петра Кочића, Херцеговина Светозара Ћоровића”. Лазаревић наглашава да су два региона остала незаступљена: „Шумадија, која је раније била јако експлоатисана, и Црна Гора која је, раније, као и сада, била под рђавим пером” (LAZAREVIĆ 2020: 50). У средишњем дијелу текста Лазаревић усмјерава пажњу на Кочићево дјело и трага за оним што је ново донио у српску приповијетку. Прије свега је то „јака доза лиризма”, затим су то јунакиње „слатке и преслатке крви”, Мргуда, Вида, Марушка и сл. Лазаревић наглашава да је Кочић те „страсне и пожудне жене” унио у српску књижевност заједно са Бором Станковићем. Истакнуто је и снажно Кочићево „осећање природе”, као и читава једна породица личности, оригиналних по схватању и по изради" (LAZAREVIĆ 2021: 53). Посебно су издвојени Давид Штрбац, Мија, Ђура, Симеун Ђак, Мићан, Вук и сл. Лазаревић наглашава и снажни Кочићев патриотизам, као и чињеницу да у његовим приповијеткама погледи јунака се крећу од „оптимизма ка све црњем песимизму” (LAZAREVIĆ 2021: 55). Интересантни су и вриједносни судови Бранка Лазаревића. Проналази недостатке и недореченост у причама „Јаблан” и „Мргуда”, не допадају му се „Молитва” и „Змијање”, а изузетно похвално говори о приповијеци „Ракијо, мајко”, за коју наглашава да „може да уђе међу петнаест најбољих приповедака које може да понуди српска приповетка” (LAZAREVIĆ 2021: 55).

У трећој цјелини налазе се огледи Бранка Милановића, Миодрага М. Вулина, Предрага Лазаревића, Светозара Кољевића, Николе Кољевића и Радована Вучковића, чије се интерпретације увелико темеље на поузданим књижевнотеоријским и методолошким оквирима и тиме стварају простор на иновативна читања Кочићевог дјела у контексту историјско-културолошких студија, усменог народног стваралаштва и фолклора, те компаративних и стилско-поетичких формација карактеристичких за епоху реализма и почетак 20. вијека у српској и европским књижевностима. На примјер, Миодраг М. Вулин посебно је анализирао карактеристике Кочићевог стваралачког поступка. Предраг Лазаревић се усмјерио на анализу жанровских специфичности и улогу лирских, са- 
тиричних и драмских структура у Кочићевом дјелу. Светозар Кољевић је указао на аспекте својеврсне шекспировски „померене реалности” у Кочићевом дјелу на примјерима из бројних прича, попут „Мрачајског проте”, „Мргуде”, „Кроз Мећаву”, циклуса о Симеуну Ђаку и сл. Никола Кољевић се бавио духовним тријумфом Давида Штрпца пред окупаторским властима и симболичким значењима побуњеног народа. Радован Вучковић је модерност дјела Петра Кочића посматрао у српском и европском контексту. Истражујући Кочићеву приватну библиотеку, као и различите облике Кочићевог дјела, расправе, преписку, приповијетке, посебно је указао на везе са Јакшићем и Шантићем, Матавуљем, Сремцем, Домановићем и Станковићем у српској традицији, као и са Тургењевом и Максимом Горким, Морисом Метерлинком, Бјернсоном у европској традицији и сл.

Овом приликом се посебно осврћемо на оглед Бранка Милановића „Кочићево мјесто у развојним токовима наше књижевности”. У првом дијелу огледа Милановић је указао на значајну рецепцију Кочићевог дјела: од Марка Цара и Кочића, преко Јована Кршића и Милана Богдановића, па све до Андрића и Димитрија Вученова. Затим је указао на Кочићеве поетичке везе са српском књижевном традицијом. Посебно је то урађено на основу Кочићевог некролога Миловану Глишићу написаног 1908. године (MILANOVIĆ 2021: 98). Поред Глишића, Милановић указује на Кочићеве поетичке блискости са Ђуром Јакшићем, Веселиновићем и Лазаревићем. Кочићев циклус прича о Симеуну Ђаку доводи у везу са Љубишиним Причањима Вука Дојчевића. Указује на блискост са Матавуљем и Сремцем, као и сродности са дјелом Радоја Домановића и Светозара Ћоровића. Милановић указује и на Кочићев утицај на младе писце, на Владимира Гаћиновића, Симу Ераковића, као и на каснији рад Бранка Ћопића. У Кочићевом књижевном дјелу Милановић са посебном пажњом сагледава ране пјесме написане угледањем на Војислава Илића („Поноћни звуци”, „Пролетни звуци”). Затим усмјерава аналитичку пажњу на лирско-медитативну прозу: „Јелике и оморике”, „Кроз маглу”, „Кроз свјетлост”, „У магли”, „Пјесма младости”, „,Тежак”, „Молитва”, „Слободи”, „Тавновање”, „Жалобитна пјесма”, „Кмети”, „Јајце”. Истакнуту пажњу посветио је социјално-психолошким причама: „Ђурини записи”, „Јаблан”, „Гроб Слатке Душе”, „Код Марканова точка”, „Јуре Пилиграп”, „Вуков гај”. Вриједносно је посебно наглашавао значај натуралистичкопсихолошких приповједака: „Туба”, „Мргуда”, „Мрачајски прото”, „Кроз мећаву”. Посебна аналитичка цјелина посвећена је циклусу прича о Симеуну Ђаку („Зулум Симеуна Ђака”, „Истинити зулум Симеуна Ђака”, „Мејдан Симеуна Ђака”, „Из староставне књиге Симеуна Ђака”, „Ракијо, мајко!”), те хумористичко-сатиричким актовкама („Јазавац пред судом”, 
„Суданија”). Међу књижевним огледима Петра Кочића, Милановић наглашава значај критичких текстова посвећених Јакшићу и Шантићу, као и двије обимније расправе: „Наша пјесма” и „Наша поезија под апсолутизмом", у којима је најизразитије оцртан Кочићев однос према народној поезији и савременом пјесништву.

У четвртој цјелини уврштени су огледи Станише Тутњевића, Стојана Ђорђића, Горана Максимовића, Давора Миличевића, Ранка Поповића, као и Милоша Ковачевића. У њима се указује на савремену контекстуализацију, политичке идеологизације, као и нове структуралистичке и постструктуралистичке оквире читања приповиједних, жанровско-генолошких, антрополошких и психоаналитичких, смјехотворних (хумористичко-сатиричких), као и лингвостилистичких квалитета Кочићевог дјела. На примјер, Горан Максимовић се бавио интерпретацијом Кочићевим смјехотворних поступака и особинама хумористичког смијеха, на примјеру циклуса прича о Симеуну Ђаку, као и сатиричког подсмијеха, на примјеру Јазавияа пред судом, те пародичног смијеха на примјеру Суданије. Давор Миличевић у огледу „Ко то тамо прича” сагледава могућности Кочићевог „двоструког иронијског приповиједања” у циклусу прича о Симеуну Ђаку (MILIČEVIČ 2021: 281). Ранко Поповић је усмјерио пажњу на Кочићеву књигу староставну, тј. на причу „Из староставне књиге Симеуна Ђака”, при чему је указао на језик и тон „пророчких оштровидих казивања", који су потпуни умјетнички финале доживјели у пародијском контексту приповијетке „Ракијо Мајко” (POPOVI 2021: 284). Милош Ковачевић је указао на данашњу изузетну актуелност Кочићеве борбе за српски језик, јер се сто двадесет година након Калајеве језичке политике, у великобосанској политици савремених Бошњака изнова повампирила идеја о стварању унитарног „босанског језика” на простору дејтонске Босне и Херцеговине.

Овом приликом посебно се осврћемо на оглед Станише Тутњевића „Петар Кочић као добри Бошњанин”, у којем су актуелизовани они аспекти Кочићевог дјела који се тичу „његовог босанског патриотизма и српског национализма" (TUTNJEVIĆ 2021: 230). Наведена расправа указује и на један несумњиви парадокс који се десио у савременој Босни и Херцеговини у којој се због унитаристичке великобосанске политике данашњих изразито србофобично настројених Бошњака десило то да су „босанско и српско, не само на државном и политичком, него и на књижевно-културном плану” постали изразито „супротстављени појмови и практично се међусобно искључују" (TUTNJEVIĆ 2021: 213-214). Тутњевић на бројним примјерима из Кочићевих саборских посланичких говора, као и политичких чланака у листовима, показује да је наш писац био снажно спротстављен аустроугарској концепцији „босанског 
политичког народа”, као и Калајевој концепцији „босанског језика”. Због тога је према Тутњевићевом мишљењу Кочић ријетко звао становнике окупиране Босне и Херцеговине „Босанцима” и „Херцеговцима”, већ је претежно употребљавао архаичнији појам „Бошњани” и „Бошњаци”. Тутњевић наглашава да се на примјеру Кочићевог дјела, поготово једночинке Јазаваи пред судом, може показати да су аустријске окупационе власти појам „Бошњак” користиле у пежоративном значењу у сасвим негативном и омаловажавајућем контексту. При томе, Кочић као „добри Бошюанин - старовник Босне” није одбацивао и потцјењивао „босански/бошњачки државни и културолошки идентитет”, али га је јасно „разграничавао од свога српског националног идентитета”. Међутим, према Тутњевићевој тврдњи „то двоје није међусобно супротстављао, него је једно другим условљавао" (TUTNJEVIĆ 2021: 217).

Тематски зборник/хрестоматија Кюига о Петру Кочићу, који је приредио за штампу проф. др Душко Певуља, представља драгоцјен примјер савремене критичке систематизације и вредновања цјелокупног дјела Петра Кочића. Као такав допринијеће не само постојаности досадашњих сазнања, њиховој научној систематизацији, те одбацивању идеолошких предрасуда и злонамјерних разумијевања, него ће иницирати и сасвим нова читања, тумачења и вредновања Кочићевог дјела. У предговору овога издања, приређивач је нагласио да је Кочић, упркос јавним и приватним страдањима и недаћама, као писац био „у милости књижевне cpeћ"” (PEVULJA 2021: 6). У сагласју с тим, нагласили смо на почетку нашега осврта да је Кочић писац који готово 120 година привлачи несмањену пажњу критике и публике. Са много основа претпостављамо да ће тако бити и у наредним деценијама. Управо је представљена Кюига о Пеmpy Кочићу најбољи показатељ тих тврдњи и закључивања.

\section{Цитирана литература}

DERETIĆ (2021). Jovan Deretić, „Petar Kočić”, Knjiga o Petru Kočiću, prir. Duško Pevulja, Zavod za udžbenike i nastavna sredstva Republike Srpske, Istočno Novo Sarajevo, s. 23-27. [orig.] ДЕРЕТИЋ (2021). Јован Деретић, „Петар Кочић”, Кюига о Петру Кочићу, прир. Душко Певуља, Завод за уџбенике и наставна средства Републике Српске, Источно Ново Сарајево, с. 23-27.

LAZAREVIĆ (2021). Branko Lazarević, „Petar Kočić”, Knjiga o Petru Kočiću, prir. Duško Pevulja, Zavod za udžbenike Republike Srpske, Istočno Novo Sarajevo, str. 49-57. [orig.] ЛАЗАРЕВИТ (2021). Бранко Лазаревић, „Петар Кочић”, Кюига о Петру Кочићу, прир. Душко Певуља, Завод за уџбенике Републике Српске, Источно Ново Сарајево, стр. 49-57.

MILANOVIĆ (2021). Branko Milanović, „Kočićevo mjesto u razvojnim tokovima naše književnosti”, Knjiga o Petru Kočiću, prir. Duško Pevulja, Zavod za udžbenike Republike Srpske, Istočno Novo Sarajevo, s. 97-112. 
[orig.] МИЛАНОВИЋ (2021). Бранко Милановић, „Кочићево мјесто у развојним токовима наше књижевности", Кюига о Петру Кочићу, прир. Душко Певуља, Завод за уџбенике Републике Српске, Источно Ново Сарајево, с. 97-112.

MILIČEVIĆ (2021). Davor Miličević, „Ko to tamo priča”, Knjiga o Petru Kočiću, prir. Duško Pevulja, Zavod za udžbenike Republike Srpske, Istočno Novo Sarajevo, s. 271-283. [orig.] МИЛИЧЕВИЋ (2021). Давор Миличевић, „Ко то тамо прича", Кюига о Петру Кочићу, прир. Душко Певуља, Завод за уџбенике Републике Српске, Источно Ново Сарајево, с. 271-283.

PEVUljA (2021). Duško Pevulja, „Književno djelo Petra Kočića u interpretativnim ogledanjima”, Knjiga o Petru Kočiću, prir. Duško Pevulja, Zavod za udžbenike Republike Srpske, Istočno Novo Sarajevo, s. 5-17. [orig.] ПЕВУљА (2021). Душко Певуља, „Књижевно дјело Петра Кочића у интерпретативним огледањима", Кюига о Петру Кочићу, прир. Душко Певуља, Завод за уџбенике Републике Српске, Источно Ново Сарајево, с. 5-17.

POPOVIĆ (2021). Ranko Popović, „Kočićeva knjiga starostavna”, Knjiga o Petru Kočiću, prir. Duško Pevulja, Zavod za udžbenike Republike Srpske, Istočno Novo Sarajevo, s. 284-293. [orig.] ПОПОВИЋ (2021). Ранко Поповић, „Кочићева књига староставна”, Кюига о Петру Кочићу, прир. Душко Певуља, Завод за уџбенике Републике Српске, Источно Ново Сарајево, c. $284-293$.

SKERLIĆ (2021). Jovan Skerlić, „Petar Kočić”, Knjiga o Petru Kočiću, prir. Duško Pevulja, Zavod za udžbenike Republike Srpske, Istočno Novo Sarajevo, s. 21-22. [orig.] СКЕРЛИЋ (2021). Јован Скерлић, „Петар Кочић”, Кюига o Петру Кочићу, прир. Душко Певуља, Завод за уџбенике Републике Српске, Источно Ново Сарајево, с. 21-22.

TUTNjEVIĆ (2021). Staniša Tutnjević, „Petar Kočić kao Dobri Bošnjanin”, Knjiga o Petru Kočiću, prir. Duško Pevulja, Zavod za udžbenike Republike Srpske, Istočno Novo Sarajevo, s. 209-230. [orig.] ТУТЊЕВИЋ (2021). Станиша Тутњевић, „Петар Кочић као Добри Бочғанин”, Кюига о Петру Кочићу, прир. Душко Певуља, Завод за уџбенике Републике Српске, Источно Ново Сарајево, с. 209-230.

Горан М. Максимовић

Одсек за србистику Филозофски факултет Универзитет у Нишу goran.maksimovic@filfak.ni.ac.rs 